\title{
O preto no branco
}

\section{Jeanne Marie Machado de Freitas}

\author{
" Vainqueur des jeux, éphèmères \\ Quoi de quel, quoi de personne? \\ Rêve de l'ombre, l'homme."
}

\section{APRESENTAÇÃo}

Este trabalho é parte de um projeto que visa, sobretudo, a tentativa, sempre incerta, de elucidação dos problemas que se situam no campo da comunicação. Caracterizá-lo como parte de um projeto ê situá-lo numa perspectiva mais ampla, que não principia, nem se esgota nele próprio, perspectiva política, que procura a ordenação desse campo, com discursos produzidos fora dele.

Entendamos: o campo de estudos e da prática da comunicação, a despeito dos inúmeros esforços dos seus integrantes, ê sombreado pela melancolia da impotência. Os acontecimentos marcantes da vida social e política, que instauram e são instaurados por processos de comunicação amplos, deslizam de maneira mais ou menos imprevisível, aos trancos e barrancos e os resultados constituem, na maioria das vezes, boquiabertas surpresas.

Afinal, o que se passou? Alguma coisa, irremediavelmente, escapa pela grelha dos conceitos estabelecidos, pelos vagares das teorias consagradas. A problemática fundante da contemporaneidade - a comunicação - é impensável? Claro está, que não se postula aqui a codificação de normas de conduta e de autoridade, organizadoras de sistemas de poder e de controle eficientes. Apesar de que, com sucesso, isso já tenha sido realizado em períodos graves da história moderna, por exemplo, o drama do nazismo que permanece, até hoje, mascarado.

Por que o nazismo foi bem-sucedido? Parece-nos que há um campo que permanece elidido, iludido, seccionado, onde as teorias se desviam, contornam, rapidamente passando ao largo. Parece-nos, ainda, que as teorias da comunicação e seus desdobramentos trabalham, essencialmente, sobre a negação desse campo que, por ser a negação negada (denegação) pode, por isso, constituir a sua verdade.

Se assim o for, trabalhamos na impostura? Damo-nos conta porem que, de um modo ou de outro, todos os outros setores das chamadas ciências humanas estão, também, mergulhados na perplexidade e na incerteza. Isso, no entanto, não consola, ao contrário, aumenta a angústia. $O$ saber, para nada?

Em L'Avenir de la Science, J. E. Renam (1823-92) exige da ciência apenas uma coisa: que ela não tenha nenhuma conseqüência. No pólo oposto, Jeremy Bentham (1748-1832), no Panopticon, propõe, ao contrário, que tudo o que seja produzido tenha um valor utilitário (para a felicidade, pois). Ou a Usui nullius ou a Scientia utilis. O dilema sustenta-se, nos dias de hoje, oscilando entre ciência pura e ciência aplicada ou, em termos mais simples, a teoria e a prática. Separação obscura, pois teoria não nasce
JEANNE MARIE MACHADO DE FREITAS é professora do Departamento de Jornalismo e Editoração da ECA-USP.

Este texto foi extrafdo da tese de doutoramento da autora, apresentada em outubro de 1986. 


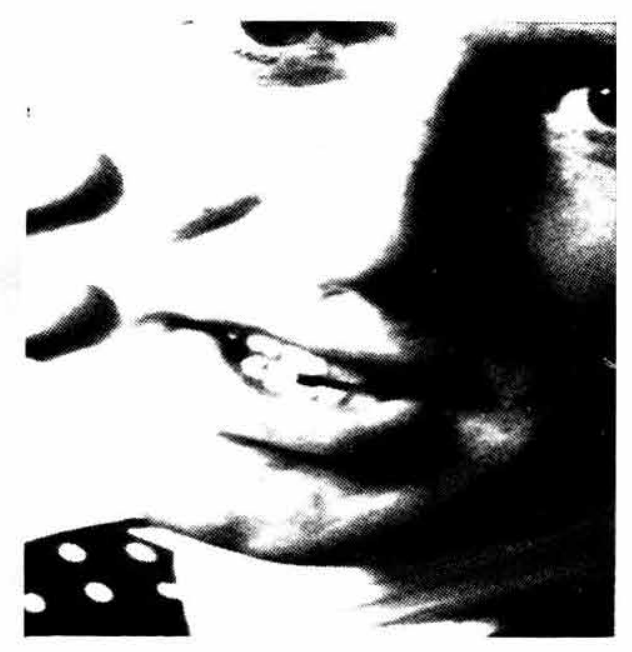

no ar e uma prática só é feita com uma representação dessa prática, portanto, a sua teoria. Além de que, a aplicaçào de conceitos, pura e simplesmente, é ilusão da experiência.

Os inúmeros erros que a história registra em todos os campos - medicina, engenharia, economia, psicologia, podem ser explicados por "errar é humano"? Ou podemos pensar que, a cada momento, no qual alguém se instrumentaliza e fecha o campo de trabalho, aquilo que escapa é que teria peso no trabalho realizado? Ao que tudo indica, a exatidão não é o complemento da verdade, nem a certeza a suplementação do saber, tampouco, a clareza é a expressão do real. Há meandros, vias tortuosas, implicações desconhecidas. Alguma coisa está ausente das concepções do mundo. Ou talvez seja a própria concepção de concepção do mundo que esteja demasiadamente presente, criando os becos sem saída. Sem-safda é a impotência própria do imaginário.

A filosofia é responsável pelas concepções de mundo ou, num termo mais moderado, a ontologia, organizando, desesperadamente, o discurso sobre o Ser. Daí as belas coisas: os universais, o Bem, o Belo, o Verdadeiro. Desse “todo" mundo, a filosofia não nos deu nada além do que uma visão, um olhar, uma apreensão imaginária. Não ê à toa que Marx dizia que, ao invés, era melhor transformá-lo. Isto ê, Marx propõe um Ideal, um projeto de ação e o faz apontando a fenda no belo ediff́cio do mundo construído pela economia clássica. Esse projeto de ação, porém, não significa regras para a ação, pois o marxismo não é uma concepção do mundo. É, ao contrário, o anúncio de que a história instaura outra dimensão do discurso e abre, assim, a possibilidade de subverter inteiramente a função discursiva como tal, essa, à qual estamos acorrentados, perdidos, nas dualidades fantasmáticas propostas pelas concepções do mundo. Freud, a seu tempo, mostra também que o homem não é um mundo, “o eu não ê mais o senhor de sua moradia" pensando-o na sua determinação em relação a outra coisa - o inconsciente que se manifesta em toda a extensão da vida humana, não deixando nenhum ato fora de seu alcance. Mostra, ainda, que isto, o inconsciente, não é o lado escuro da consciência, mas aquilo que molda a vida humana movido por uma única mola: o desejo.

Lacan, no caminho de Freud e recorrendo a Saussure, elabora uma tópica denunciando a autonomia do sujeito livre tal como o idealismo o apresenta. Estabelece a função significante da linguagem e elabora a teoria do significante, colocando o inconsciente como causa formal, o imaginário como o conjunto de variáveis que, fixando-se sobre o quadro simbólico forma o fantasma e o real, nessa topologia, é como causa exterior ao sujeito, o impossível de ser formalizado. Ele (o real) se diz numa estrutura, isto é, uma combinatória de elementos permutáveis, comandados por uma repartição, na qual a divisão permanece invariante: o simbólico representa essa invariância.

Essas passagens não foram feitas com a simplicidade com que são expostas aqui. Permitiram-na, um longo olhar para trás, tanto na direção do mito, da religião, quanto do percurso feito na formação do

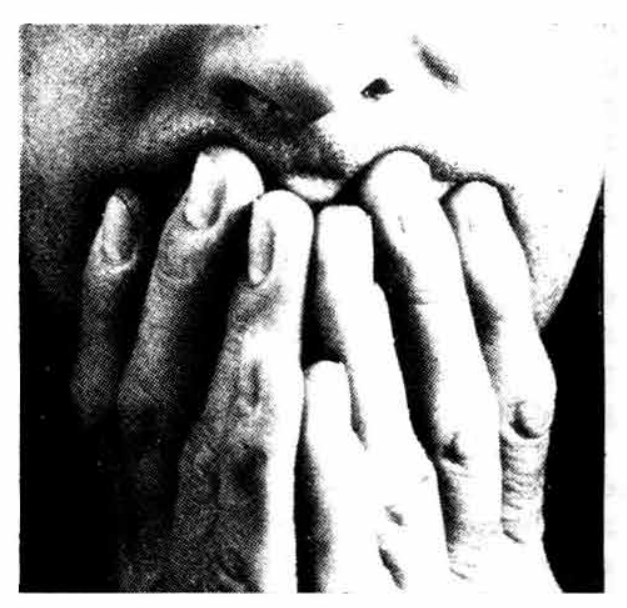
saber, reconhecido como ciência moderna, onde se incluem a lingüística, a lógica matemática, a teoria dos conjuntos e a psicanálise. Permitem sacudir o jugo do pensamento herdado no qual, uma parte essencial, não é senão mera racionalização da autofinalização da sociedade na natureza, na razão, na necessidade, nas leis da história, fixando-se nas finalidades, na causalidade, na motiva- 
ção, no reflexo, na função, nomes da razão necessária e suficiente.

Deve-se, ao fundamento do pensamento herdado, a efetivação do fantasma da eficácia (eficácia de quem, tendo em vista o quê? para quê?), conduzindo à formação de instituições burocratizadas nas quais a finalidade é o objetivismo e o progressismo, de onde foram cassadas a realidade e a vida concreta que só af aparecem como fetichismo da coisa e da percepção imediata. Derivam ainda desse pensamento as práticas de ensino encerradas no empobrecimento e na deterioração, tornando as universidades túmulos das iniciativas e templos da onipotência da técnica.

A comunicação que é vida e, portanto, morte e perturbação, carrega no seu ensino e na sua prática esse fardo tradicional. Suposto campo da interdisciplinaridade lida com a transferência de conceitos precários e empobrecidos, transformados em artefatos estáveis, limitados e mortos. Ao enfatizar a prática, torna-a uma atividade inteiramente racionalizada, um fazer imediato e obscuro, sem possibilidade de elucidação de sua relação com o saber. Transforma-a, assim, em atividade alienada e cega e, pior ainda, transformam a ação, que é, na comunicação, essencialmente ação política, em ação têcnica.

Decorre, dessa postura, o álibi pedagógico: as diferentes propostas teóricas são consideradas como diferentes pontos de vista; a tolerância emerge na relação com a impotência; o concreto se torna o vazio histórico. Sustenta o ediff́cio, o prinćpio unitário: o utilitarismo e o culto da eficiência, aceito,

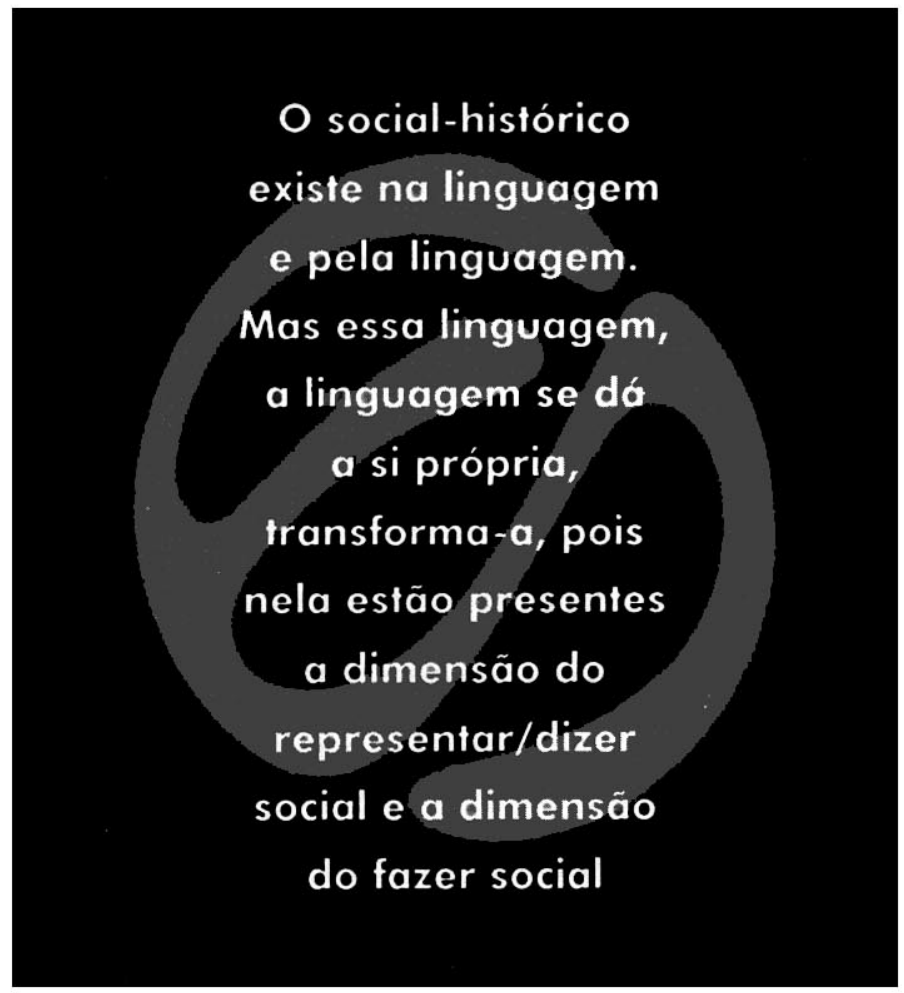
de uma vez por todas, como realidade intangível de onde são afastados o prazer e o gozo, mesmo que, momentâneo, da descoberta compartilhada.

Essas palavras, que apresentam o trabalho, situam a autora e suas preocupações.

\section{Ponto De Partida}

Partimos da escrita jornalística. Afastamo-nos, assim, da sociologização, uma determinante nos estudos de comunicação e, com isso, situamo-nos igualmente distanciados das teorias que, fundadas em postulados positivistas, concebem o mundo como um conglomerado de funções as quais cabe ordenar e, em conseqüência, controlar.

Interrogamos o fazer jornalístico no lugar em que este ganha corpo e se concretiza "a escrita" - lugar que institui as práticas silenciosas que registra, lugar que faz, contando, os acontecimentos que recorta e meio utilizado para passar da desordem à ordem. A interrogação privilegia, por isso, um suposto: a linguagem como instituinte, a linguagem como determinação, partindo do fundamento segundo o qual o homem vive e se faz no mundo da linguagem, engajado ar por um discurso que corre desde as origens dos tempos e no qual está inscrito. A dimensão do discurso instaura um espaço "onde se defrontam, num estranho pacto, o sexo e a morte, o símbolo e o corpo, o trabalho e o desejo, o sujeito e a história", campo também chamado inconsciente ${ }^{(1)}$.

Assim, aquilo que $\epsilon$, incidentalmente, tocado ou instrumentalizado nos estudos da comunicação $\epsilon$, neste trabalho, o ponto de partida, o fundamento, a razão e a justificativa. Remamos contra a corrente. Negamos que a comunicação possa ser reduzida a uma mera tecnologia de empacotamento e transmissão de mensagens, assim como negamos à linguagem a função de transportadora de idéias, signifícados ou o que mais seja.

Sediamo-nos no originário: o Verbo que estava no prinć́pio, entendendo-o como Davar, que tanto diz ação, como palavra. Em decorrência, faz parte também dos fundamentos do trabalho a concepção segundo a qual não há realidade pré-discursiva. Cada

1 Essas formulaçøes foram mais amplamente tratadas no nosso trabaIho Os primeiro de maio (polftica, ideologia, inconsciente), Serie Pesquisa Comunicaçăo Jornalistica e Editorial, ECA-USP, 1988. 
realidade se fundamenta e se define sobre e por um discurso, mesmo porque, para darmos conta da dita realidade, não podemos fazê-lo sem um discurso que a torne tal para nós e para aqueles que nos ouvem.

Essa concepção tem implicações graves em relação ao saber reconhecido (o conhecimento) e, mais ainda, cria problemas quando o argumento fundante concerne à produção, ao trabalho, já consagradamente entendidos por referência a uma determinada leitura a partir da conceituação marxista. Deixamos, por isso, às trevas originárias a relação do trabalho à palavra, pois ao mítico pertencem todas as soluções postas ao problema das origens e mesmo as questões que a elas se referem: criou a sociedade dos homens a palavra que os une ou criou-a o trabalho que os diferencia? Nesse mesmo limbo, situamos a pergunta: o que é determinante, o pensamento ou a ação? Ao invés de colocar nesses termos o problema, o que o transporia em uma falsa questão, prosseguimos no caminho aberto pelo gesto fundador da teoria lingürstica: a instituição de uma barra que, introduzindo na língua uma dissociação, separa e distingue, insoluvelmente, os conceitos, as idéias, os "significados" e a materialidade própria que os gera e, ao mesmo tempo, permite e suporta o laço entre aqueles que falam, o "significante". No entanto, falamos aqui de instituição da linguagem e do social. E aquilo que ouvimos, lemos (pois ler nada mais é do que outra forma de ouvir), parece não ter nenhuma relação com este fundamento a que nos referimos, confundindo a compreensão dos efeitos que gera. A não ser que introduzamos aqui um terceiro termo - a "referência"(2), justamente o que resulta da constituição de um discurso como um laço (social).

O significante, como tal, não se refere a nada além que o discurso, a um modo de funcionamento, a uma utilização da linguagem como laço. Em outras palavras, e o significante que, no tecido da linguagem, anima, e com isso dá vida, constrơi, para os homens, as coisas, a realidade.

Nessa tessitura é que são produzidos os significados, no passo da instituição do social e, com ela, a instituição dos próprios homens. Torna-se impensável, nesses termos, qualquer coisa fora desse laço, fora do social, fora de sua constituição na linguagem.

Podemos dizer, então, que a referência e formada pela enumerabilidade dos discursos sociais, engendrados ao longo do tempo, depositados no movimento da história, discursos histórica e socialmente produzidos, concretamente falados.

O significante, isto que estamos lendo-ouvindo, refere-se a essa enumerabilidade, não sendo, por isso, disposto, a despeito da aparência, na linearidade de seu encadeamento. Essa linearidade impõe-se apenas na direção em que é orientado no tempo de sua emissão, pois a cadeia emitida mantém, suspenso e sustentado por infinitos nós, tudo aquilo que a história constrói ou teria construfdo, e que se articula, verticalmente, em cada um desses nós.

Repetimos a imagem que nos parece expressar essa afirmação: tessitura de uma complexa rede que se desdobra sobre "La mare" do significado, como diz Lacan"(3).

A comunicação implica a referência. Aŕ reside o drama, pois a barra - a separação da dimensão do significante e da dimensão do significado - tem função primordial: nem tudo é articulado, nem tudo pode ser ordenado. A barra tem função de censura e só mesmo a acumulação de uma força pode levantá-la, permitindo que os laços se refaçam, revolucionem ou reformem os efeitos dos significados. Tem, assim, a força e o peso da Lei.

Af́ se marca o mérito de Saussure: a enunciação e a compreensão da função da barra que, ao saltar do significante ao significado que flui, estabelece o limite real. Podemos assim compreender a instituição do social como o processo instituinte que simultaneamente cria e é determinado por suas instituições e atribui a estas a função de barra, entendendo por instituições não apenas aquelas que dão a vestimenta jurfdica das relações sociais, mas essas próprias relações, propostas como um fazer, ao mesmo tempo e, em cada caso absolutamente específico, como rede - laços, portanto, sancionados e simbolizados, patamar de escolha e de eliminação.

Essas considerações apontam para a radical ambigüidade do significante: enquanto constituinte dos laços sociais, no imperativo da Lei, é o suporte do instituŕdo, do estabelecido, mas, ao mesmo tempo sustentando a multiplicidade de dimensões que, em complexas relações de causalidade, são tocadas pelo movimento real, é também a causa do instituinte, da possibilidade de subverter completamente a função do discurso instituŕdo.

A cadeia significante comporta, contraditoriamente, o estabelecido, o reconhecido, o legislado, o mesmo, o institufdo e também o subversivo, o instituinte, a alteridade e 
aquilo que teria sido. A linguagem, o sistema de significantes, não é, por isso, apenas o campo onde se inscrevem os discursos no decorrer da história: ela os contém e os transborda.

$\mathrm{Na}$ construção desse quadro de referências do trabalho, impõe-se o esclarecimento do conceito de história, aqui observado. Poderfamos aceitar a conceituação consagrada: história é a "história da luta de classes" e enveredar pelo caminho á indicado. Mas os simplismos que usualmente ocorrem, em decorrência da problemática precisão do termo - classe - obrigam a um desvio que não propõe, necessariamente, a sua negação. Partimos da concepção trivial: nenhuma sociedade existe se não organiza a produção de sua vida material e a sua reprodução enquanto sociedade. Isto supõe organizações, pois nem uma nem outra dessas condições são ditadas por leis naturais, e tampouco podem ser pensadas como resultantes de considerações puramente racionais e determinadas. Ou seja, ao lado do puro aparato tecnológico, que propicia a produção e a reprodução, uma sociedade se manifesta de maneira tangível: faz-se, é um permanente fazer-se de si própria. A história é esse mundo do fazer humano: escavação de estrias, de linhas de forças no real que ela própria produz, construção de pontos de apoio para a ação, um fazer com propósito determinado(4).

Se esse real fosse simplesmente o visível, o dado, o substrato natural ao que cumpre transformar, ou ainda se o supuséssemos como exclusivamente racional e determinado, produto exclusivo da ação humana, o problema do fazer não se colocaria pois tudo estaria dito, previsto, organizado. Por isso, a história compreende, ainda, uma margem de indeterminação que, nem por isso, não significa um fazer. A sociedade, os momentos desse fazer, é que impõe os esquemas, as condições operantes, as instituições. É ấ que se estabilizam os conjuntos de regras de identificação, a eleição das possibilidades, determinadas pela lógica que as domina. Mesmo assim, a sociedade instituŕda não exclui o indeterminado, $o$ acaso.

O histórico e o social que vão juntos (histórico-social) são, em última instância, a indissociabilidade do fazer e do dizer, isto $\varepsilon$, dos laços que se estabelecem entre os homens, fazendo-os homens sociais. Não se revelam, porém, como a adição indefinida desses laços, nem como seu simples produto: "são o coletivo anônimo, o humano impessoal que preenche toda a formação social dada mas a engloba também, que encerra uma sociedade, distinguindo-a de outras e as inscrevendo todas numa continuidade onde, de certa forma, estão presentes aquelas que estão alhures e aquelas que vão nascer. São, de um lado, estruturas dadas, instituições e obras materializadas, quer sejam obras materiais ou não e, de outro, aquilo que institui, estrutura, materializa. São a tensão e a união entre a sociedade instituinte e a sociedade institúfda, a história feita e a história se fazendo"(5). Resumidamente: "o social-histórico é a unidade da dupla multiplicidade de dimensões na simultaneidade (a sincronia) e na sucessão (a diacronia), denotada habitualmente pelos termos sociedade e história"(6).

O social-histórico existe na linguagem e pela linguagem. Mas essa linguagem, a história se dá a si própria, transforma-a, pois nela estão presentes a dimensão do representar/dizer social e a dimensão do fazer social. A instituição de uma sociedade é, assim, a instituição de um certo mundo na linguagem, de uma exigência de significações e de respostas, a cada momento, colocadas a essa exigência. Essa exigência resulta na construção de um prinć́pio de equivalência entre significantes e significados, que responde à instauração do Poder.

No entanto, uma resposta suturante só é possível no universo mítico ou, dito de outra forma, pertencendo ao reino do imaginário, campo privilegiado para o enraizamento da ideologia. Se tomarmos o exemplo no campo religioso, verificamos que o significante Deus é, ao mesmo tempo, criador de significações, elemento central do mundo monoteísta e a fonte do ser de cada um, norma e origem da Lei, barra que separa a região sagrada da região profana, sendo, por isso, o termo que rege a autoridade do significado.

Seguir o movimento da cadeia significante (subentendida no exemplo acima nas implicações do significante Deus) permite evidenciar as redes de significados que se vão organizando, os nós e o trajeto que o peso do fazer histórico foi marcando e os momentos de emergência de "outra coisa que".

É preciso ter em mente, porém, que o movimento transborda o feito e o dito, estendendo-se ao passado que o sustenta e apontando as possibilidades de um futuro que seria ou que será. Nessa perspectiva, podemos ler a escrita jornalística, ler esse "se" (indeterminado) que se escreve nos jornais, supondo, em vista disso, que a escrita pode ter outra leitura, diferente daquela (determinada) para a qual foi produzida. Esses supostos
4 As idélas que se seguem pagam seu tributo a C. Castoriadis. A instituiçăo imaginâria da sociedade. Săo Paulo, Paz e Terra, 1986.

5 C. Castoriadis, op. cit., p. 414.

6 Idem, p. 414.

\section{Dezembro \\ Janeiro \\ Fevereiro} 1990-1991 


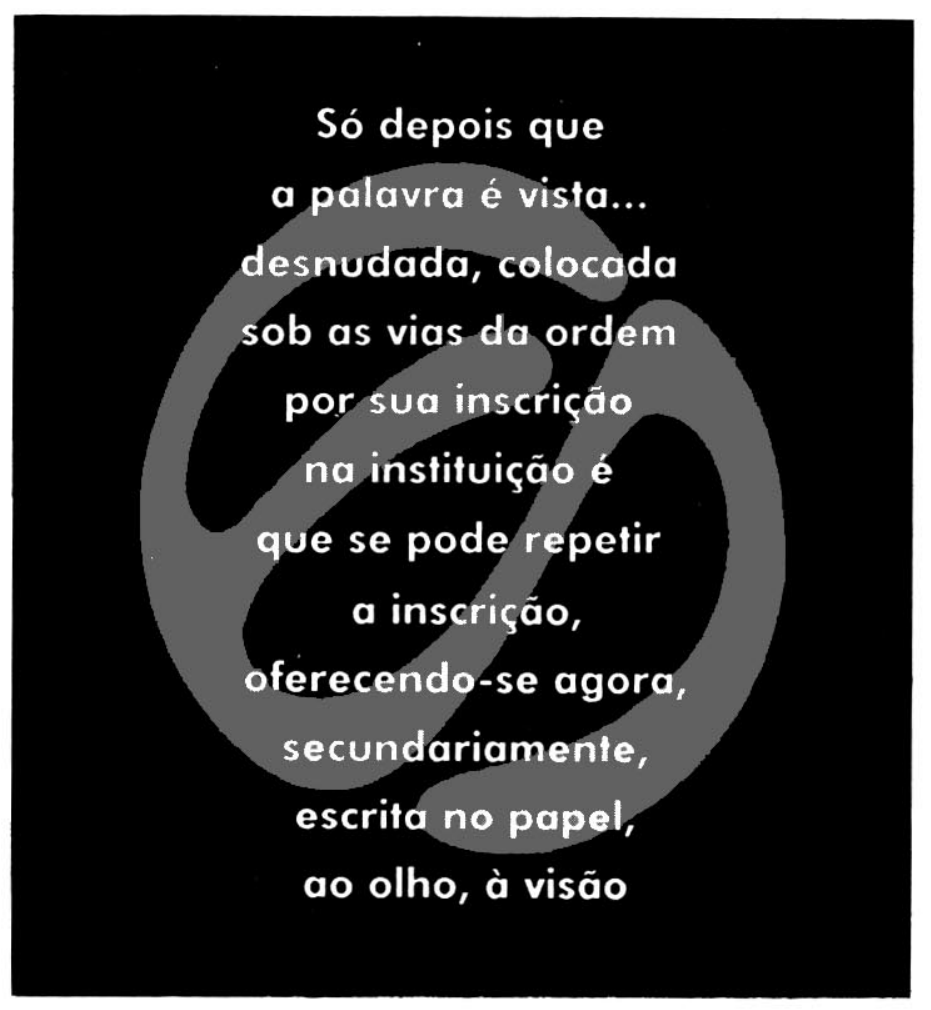

permitem que o trabalho coloque-se em outro ponto de vista frente à visão "realista" que separa o campo social do.campo dos discursos, ampliando, dessa forma, a problemática envolvida na comunicação.

Poderia surgir, agora, uma questão: por que não dizer simplesmente discurso jornalístico, ao invés de escrita jornalística? A resposta provém de duas razōes. Em primeiro lugar, uma razão restrita aos fundamentos da proposta: a escrita não se registra da mesma forma que o significante. E sustentada pelo discurso, isto $\varepsilon$, aquilo que, na linguagem, funciona já como laço social, instituindo significaçōes. Nessa precedência, a existência do escrito deve-se, primordialmente, à existência da barra que divide, distingue, a ordem dos significados e a ordem dos significantes. Em segundo lugar, os discursos (quatro discursos, na referência lacaniana que orienta estas considerações(7) são caracterizados pelo termo que se coloca na posição de agente. Mas o agente não $e$ aquele que age: $\varepsilon$ aquele que faz agir.

O jornalismo, nesse sentido, é parte de uma realidade histórico-social, na qual "aquele que faz agir" não é exatamente uma identidade jornalística. E, mais ainda, se no discurso funcionam relações - laços - que têm como efeito a produção de uma coletividade e, com ela, a produção de uma realidade para uma dada sociedade, é porque há ǻ uma ordenação que não é feita por acaso mas é o resultado de uma articulação entre aquilo que se concentra como efeito do discurso e algo que se condensa em torno de uma fenda e como uma fenda. Essa articulação resistente provém do "se" que se escreve e dá a cada discurso uma modulação especial.

A pintura de Tomie Ohtake ajuda-nos a compreender essa articulação: na superff́cie compactada da tela delineia-se uma nesga, um traço que, suave e lentamente, vai vencendo a rigidez da superfície. A nesga é, ao mesmo tempo, uma condensação de cores e uma fenda que se abre na superff́cie compactada. O efeito da tela resulta da articulação entre a superfície, concentrado de cores (o que a faz compacta) e o traçado da fenda. A diferença das telas é marcada pelas modulaçỗes que essa articulação produz, o prinć́pio porém é aparentemente o mesmo em todas as telas. Também a escrita $\hat{\epsilon}$, assim como a tela, o que permite, no nosso caso, marcar a diferença: é fenda compacta, fazendo o traçado diferencial de cada discurso. O traçado provém do fundo do discurso, deixando entrever que lá está um ponto de atração irresistŕvel, insistente que, imantando a rede formada pelo discurso, a liga e a dirige. $O$ traçado, pegadas dessa Coisa que se fala em outro lugar, e, por essa razấo mesma, apropriadamente apreensível pelo saber que a psicanálise provê ao fundar o campo de sua administração sobre o Isto, que Freud nos ensina a designar pelo nome: inconsciente.

\section{DO PODER E DO SABER:}

\section{O traço, o escrito, a fala}

Os canoeiros do Araguaia seguem os traços invisíveis da estrada flutuante e as caravanas errantes seguem, nos desertos, vias já traçadas.

Traços escritos por quem e onde ninguém sabe, da mesma forma que ninguém sabe porquê e para quê as pictografias maias e astecas ou os calhaus de Mas D'Azil. Esses traços, que não são sempre fabricados da mesma forma, podem ser pensados como letras de um escrito que, reunindo coisas heteróclitas, presidem um acordo, uma aliança, que marcam diferenças, permitem o reconhecimento.

Assim proposto, o escrito se revela, não pelas imagens que dá a ver ou pelas signifi7 Cf. Encore, J. Lacan. Paris, Seuil,
1975.



Dezembro

Janeiro

Fevereiro

1990-1991 
cações que engendra, mas pelo ato que produz, que testemunha ou que evoca (os canoeiros não se perdem no rio, nem as caravanas, no deserto).

As letras desse escrito, erráticas, podem se inscrever numa palavra ainda em rota, na expectativa sempre aberta do encontro, e deslocar alianças feitas, criar novas, pois nenhuma pavimentação segura a estrada flutuante, nem os caminhos do deserto.

O escrito está assim, no limite das palavras, no horizonte dos caminhos e, por isso, como ato que $\hat{\epsilon}$, quebra as falas, af se intercala e faz a distância entre as ilhotas de palavras que deslocou, separou. Nesse movimento, a fala condiciona e produz o escrito, e o escrito, em contrapartida, sustenta a fala e põe à prova sua veracidade.

Se retomamos a sugestão de aliança, de pacto aqui, podemos dizer que, entre o escrito e a fala, entre Um e Outro, coexistem várias formas de relações e, transportando um pouco mais longe essa sugestão, arriscamo-nos a afirmar que, do encontro desse traço que serpenteia no fio da história e das falas que o produzem, se devem as formas que as coletividades humanas adquirem.

Dissemos traço e não escrito, porque sendo o traço o elemento do escrito, o escrito "não pode viver ou fazer viver se pretende se identificar a esse ou aquele traço, detê-lo, controlá-lo, fascinação essa que sustenta as sociedades totalitárias"(8).

O cetro, o cocar, o anel papal, a faixa presidencial, por exemplo, são traços indicadores de um lugar vazio, de poder e, o fascínio pela apreensão, pela identificação do traço e do suporte, caracterizam o totalitarismo, e aquilo que é potencialidade, indicação transforma-se em pura determinação: cassetete policial, terrorismo, inquisição.

\section{Inscriçōes - Instituiçōes}

Vamos transportar agora essas considerações a um campo mais restrito, a fim de, nessa passagem necessária, introduzirmos a nossa questão sobre a escrita jornalística: o campo das instituições.

As instituições dão forma às sociedades $\mathrm{e}$, do nascimento à morte, oferecem-se como formas de inscrição no social a cada um, fazendo desse um, um como os outros. Se dão forma às sociedades, o fazem por sua própria forma de inscrição nela, e pelo entrelaçamento que mantêm umas com as outras, nesse social, o que nos permite pressupor que o momento de inscrição já estabelece uma certa relação entre o escrito e a fala, estabelece um certo dever-ser. As condições já estão postas a partir daf, e os fios destinados a dar o nó do acordo a ser firmado já estão estirados. Dessa maneira, "o ato produtivo (o escrito), onde a palavra é dada, vocalizada, evocada para ser vista e para que se siga com o olhar sua abertura cadente num espaço onde a produção de imagens se ramifica sobre as multiplicida-

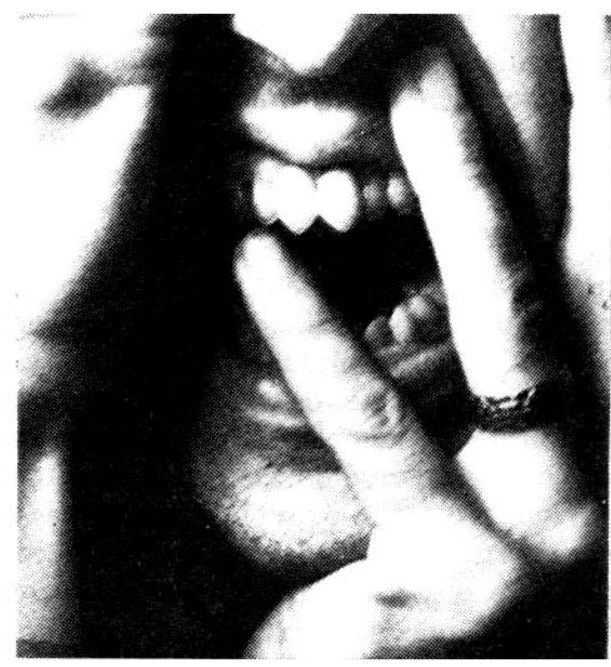
des das fontes imaginárias"(9), e já passado.

Só depois que a palavra é vista, apreendida, desnudada, colocada sob as vias da ordem por sua inscrição na instituição é que se pode repetir a inscrição, oferecendo-se agora, secundariamente, escrita no papel, ao olho, à visão.

$\mathrm{O}$ olhar, como órgão do imaginário que ê, encontra ấ um limite. Esta relação, posta entre o escrito e a fala, pode ser mais ou menos fechada, resultando em instituições igualmente mais fechadas ou menos fechadas. Tudo depende do escrito que, sustentando-se no ponto extremo do discurso (o laço social que mantém a inscrição), resiste à prova pela qual a palavra sucumbe ou ricocheteia, ou seja, se ela provoca evocação ou cai no silêncio. Se o resultado desse ato for a evocação, então a palavra que cercava a inscrição desloca-se, parte-se, permitindo detectar não somente o escrito sobre o papel, mas o inscrito na própria instituição.

Um exemplo limite de instituição fechada pode ser encontrado no livro de George Orwell, 1984. Af, o corte rude e total das manifestações divergentes do Um, mostrandose na obsessiva redução de dicionário, dos gestos, da degradação, o cerco asfixiante da ordem e da disciplina indicam a criação do Outro (A), como absoluto, completo, sem

8 Le nom et le corps, Daniel Sibony. Paris, Seuil, 1974, p. 11.

9 Idem, p. 12. 
falhas. O amor, que evoca e transgride, mostra, num relance, a extensão do horror. É interessante registrar nesse rumo do pensamento que nos dias atuais, onde se lamenta ou celebra-se a morte das instituições, a comunicação de massa acumula produções que se situam na mesma temática de Orwell. Isso parece indicar que essa morte manifestada na dispersão das instituições, tradicionalmente conhecidas, seja, ao contrário, a sua vida, isto $E$, formas institucionais ainda mais tenazes, mais cerradas.

A hipotese se organiza na direção dos esquecimentos, como se escreve essa "alguma coisa" que insiste, não diz seu nome, é pressentida, pressiona, sombra indizfvel, gerando efeitos cada vez mais monstruosos?

Se por outro lado a instituição é uma certa relação entre o escrito e a fala e se o escrito é ato que não se pensa, nem se imagina sem as palavras das quais ele faz as bordas, que faz viver ou que anula, sendo no entanto intrinsecamente diferente delas, podemos dizer que, quanto mais se procura ajustar os dois termos dessa diferença no artifício da isomorfia, mais se estreitam algumas formas do fazer humano, as políticas, as eróticas (as primeiras, reduzidas à técnica e as segundas à brutal visão da pornografia).

Função delegada: Tu és...

A fim de completar essas consideraçōes sobre a forma de inscrição social da qual estamos tratando aqui, é preciso acrescentar ainda mais um ponto. Aceitamos que as sociedades se constituem em relação a alguma coisa, uma origem situada no interior delas proprias (sociedades autônomas), ou fora delas próprias (sociedades heterônomas), origem esta que permite a formação de identificações e de modos de pertença de cada um ao todo considerado. Esses modos de pertença são organizados e determinados, permitindo-nos pensar que nessas organizações e nessas determinações, há um lugar de onde é sussurrado "tu és". As instituições seriam um desses lugares, desempenhando, se assim podemos dizer, uma função delegada.

Para tentar clarificar o que estamos entendendo por função delegada, recorramos aos fundamentos de nosso trabalho. Sustenta-o, como prinć́pio básico, a relação $S(A)$, isto $\hat{\epsilon}$, o sujeito $(S)$ determinado pela linguagem e pela fala, dependendo fundamentalmente dos significantes da linguagem, chamado campo do Outro (A), lugar de significantes. A lingüŕstica nos ensina que o significante $\varepsilon$, por natureza, descontínuo, formando cadeias que se recortam e se cruzam, e na psicanálise se aprende que o significante, assim entendido, $\hat{\varepsilon}$ aquele que representa um sujeito para outro significante.

A colaboração da psicanálise permite dizer que nessa relação falhada instaura-se ao mesmo tempo uma perda essencial e sobre ela, a partir dela e por ela constrói-se a possibilidade da socialidade, processo que tem como resultado o sujeito dividido (S) e a Divida. Por socialidade se entende, então, a instauração de um corte e de uma falha pela qual os sujeitos são, uns para os outros, os representantes daquilo que falta(10). Instaura-se af tambem a língua como cadeia de equívocos, pois o que af se oferece e só af pode ser oferecido são os representantes, as figuras da perda. Diz Lacan: "Os objetos (a) não são senão os representantes, as figuras. $O$ seio - como equfvoco, como elemento característico da organização mamffera, a placenta por exemplo - representa bem essa parte de si mesmo que o indivíduo perde no seu nascimento e que pode servir para simbolizar o mais profundo objeto perdido. Para todos os outros objetos, eu poderia evocar a mesma referência"(11). Esses objetos, apesar de inumeráveis, podem ser contados: mille e tre, como o queria D. Juan.

\section{O poder}

No entanto, se a socialidade supõe uma determinação, a sociedade supõe organização, isto $\epsilon$, gestão, isto $\epsilon$, força, isto $\epsilon$, poder.

Firmando-nos nessas considerações, parece-nos possível pensar o Poder como uma forma de gestão da falha. Estabelecendo-se como um significante, idêntico a si mesmo, identidade dialeticamente encobridora da falha, é af nessa "negação da falha" que repousa a lógica do Poder que, "realizando-se no ato mesmo de encobrir, se constitui como objeto mesmo do desejo do sujeito, o objeto mais não sendo e nunca do que o símbolo de sua ausência. Semelhante operação como a da logica - que ordena as proposições compostas independentemente da verdade ou da falsidade das proposições elementares - insere o individuo num domínio de certezas. $O$ único imprevisfvel, sendo af o Poder, instaura-se através dessa suspensão, a previsibilidade absoluta. E os obstáculos que o indivíduo encontra não são senão efeitos previś́veis da imprevisibilidade do Poder"(12). 
Se retomamos agora a relação $S(X)$, relação que indica que o que falta no sujeito o Outro não completa, pois af também falta, vemos que justamente é esse "saber de falta" que leva o sujeito "à potência da condição absoluta (em que o absoluto também quer dizer destacamento)", o que significa condição de sujeito desejante, sujeito no processo, em ato de sua vida. Mas como age o Poder? "O significante do Poder, negando toda falha que não a sua, dá antes vazão à demanda, que sendo demanda incondicional de amor é a garantia de sujeição. Quanto ao desejo, precisamente por subverter a demanda, será erradicado"(13). Só ele sabe.

Esse significante, como significante que e, jaz na língua, e ar que se faz senhor, af no cristal da língua: "me ser a mim mesmo"(14). E, mais ainda, esse significante se faz senhor na sua articulação com o saber, que é a sua garantia.

\section{O saber}

Vejamos agora essa articulação. Para isso puxemos o fio dos saberes que as sociedades foram criando, nas pontes que foram construindo, em direção ao Outro que as constitui, saberes que se efetivavam de várias formas: mito, religião, filosofia, ciência. A despeito da forma pela qual são apresentados, como se desdobrando numa temporalidade, não se eliminam uns aos outros, pois pela razão mesma de serem articulados, constituem cadeias que se recortam, cruzam-se, depositam-se ou se agitam no seio da linguagem, tendo em comum o fato de serem articulados: falados, escritos, inscritos. Assim sendo, nós não poderfamos pensar essas articulações sem supor que alguma coisa que as articula (a presença do significante), não estivesse lá, desde sempre, fazendo um laço, estabelecendo um discurso. Se pensamos que as coletividades humanas desenvolvem práticas comuns, essas práticas são articuladas, ordenadas, e dar só podemos inferir que se são ordenadas, é porque um significante as ordena. A prática, assim suposta, já está tramada numa articulação significante, princípio de todo o saber, sem o qual não haveria prática. Esse saber está lá, mesmo que essa articulação não tenha ainda se desprendido do saber-fazer. $O$ traço dessa presença primeira, desse saber que se desprende do fazer, nós a encontramos na tradição filosófica, na conexão do significante do Senhor com o saber do escravo.

A divisão que se opera af, do significante do Senhor ao corpo perdido pelo escravo para que ele não se torne outra coisa senão aquele onde se inscrevem todos os outros significantes, funda uma forma de laço social - um discurso, inaugurando uma história. Nesse discurso, a psicanálise mostra o intervalo (na articulação Senhor-Escravo) onde se localiza o saber: "no lugar do Senhor se estabelece uma articulação nova que, no lugar do escravo, não se insere no saber, mas no produto do saber. O que Marx denuncia como espoliação, sem se dar conta que, no próprio saber, já se opera a perda"(15) o a mais do gozar ou a mais-valia do gozo. Assim, as funções próprias desse discurso: Significante Senhor-Saber são definidas por uma divisão: a divisão do significante do Poder em relação ao saber, marcando ferozmente um discurso, para o qual o marxismo é apresentado como as palavras de um Evangelho que anuncia a sua extinção e a possibilidade de estabelecimento de uma nova forma de laço social, da formação de um novo discurso. Dessa maneira, tudo o que se produz no trabalho desse discurso, concernente à verdade do Senhor, isto $E$, o que ele oculta como sujeito, $S(A)$, vai juntar-se a esse saber enquanto dividido e recalcado e, mais ainda, está ấ e ninguém compreende nada, “o que não justifica pensar que as verdades estão condenadas a serem obscuras"(16).

Voltando, sobre os nossos passos, recuperando a proposta de instituição enquanto função delegada, podemos pensá-la como lugares em que se apresentam os representantes dessa representação, dessa divisão e desse recalque do saber. Em conseqüência, podemos entender os representantes como significantes da representação, cuja significação encontra-se em outro lugar, além deles mesmos. Por exemplo, quando pensamos nos jornalistas no seu trabalho, digamos, numa entrevista, se bem assumem sua função, af permanecerão, registrando e transmitindo, na pura função de significante, pois a significação situa-se através de uma sutil rede de reenvios, em algum outro lugar para além deles próprios: a instituição jornalística.

Mas toda representação requer um sujeito que a sustente e em relação ao qual ela signifique, e é af justamente que reside o problema, pois se formos pensá-lo, digamos assim, como um sujeito puro "sustentando-se no mundo com a sua Weltanschaung original ou originária, então o caminho da verdade passa - como nos indica ainda uma psicologia e uma psicossociologia retrógradas - pela pesquisa, pela totalização, pela estatistica dos Weltanschaung. $\mathrm{E}$ as coisas poderiam ser assim se houvesse no mundo

13 Idem, p. 79.

14 Les quatre discours, Jacques Lacan. Seminaire 1969-70. Mimeografado, p. 71.

15 Idem, p. 34.

16 Idem, p. 40. 
sujeitos que fossem encarregados, cada um, de representarem certas concepções do mundo"(17).

A articulação da estrutura do significante oferece-nos condições para resolver o problema, pois se é verdade que um significante representa o sujeito "para" o outro significante, repito, uma relação articulada, não pode haver sujeito sem que, em algum lugar, esse sujeito desapareça. Se ele surge determinando um sentido, é porque desaparece (aphanisis, diz Lacan) no lugar do Outro e passa a ser aquele que dá nome aos bois. Por isso, chamemo-los pelos nomes $S_{1}$ e $S_{2}$, e acrescentemos que $S_{1}$ é significante do poder e $S_{2}$ significante do saber, entre os quais há uma luta de vida ou morte, luta pelo poder de, dando vazão à demanda, retorná-la na forma invertida: “tu és". É em relação a esse "tu es" que podemos pensar as instituições como representantes da representação na função delegada. Talvez seja por essa razão que os jornais estabelecem o seu manual da redação.

\section{Prévia necessária}

Dissemos que as instituições vêm a ser condições já postas, formas de inscrições asseguradas, pelas quais se dá o acessu à sociedade. Nesse sentido, podemos sugerir que o jornal de amanhã, sendo inscrição na instituição, não é uma página em branco. Ấ já se desenham lugares, rubricas, normas e uma série de operações pelas quais o visto e o ouvido, o discernivel, o heterogêneo e as fraturas possam se oferecer como discurso, indiscernível, homogêneo, sutura ou, mesmo, silêncio. Esse processo envolve duas problemáticas correlativas:

1 - A problemática da práxis da comunicação. Se entendemos por práxis, de forma ampla, "a ação concertada pelo homem, que o capacita a tratar o real pelo simbolico"(18), podemos perguntar: como se articulam os conceitos af necessários? Como se delimita o campo de sua atuação?

2 - A problemática do conhecimento. Supondo que a informação, eixo fundamental da prática jornalística, seja uma forma de conhecimento, a problemática diz respeito à constituição de um discurso do saber, à constituição de uma realidade.

\section{A comunicação}

A respeito da primeira problemática temos que o conceito de comunicação opera sobre um modelo bastante simples, pois e talhado nas dimensões do real: um homem fala a um homem, de onde se constrói o esquema fundante - E-M-R. Esse esquema pode ser lido da seguinte forma: na multiplicidade dos seres falantes é possfvel estabelecerem-se dois pontos: um ponto de emissão (E), outro de recepção $(R)$, simétricos, dotados das mesmas propriedades, indiscernf́veis, portanto, a não ser na sua dualidade numérica.

Tanto aquele situado no ponto de emissão - o emissor -, quanto aquele situado no ponto de recepção - o receptor - são pensados apenas como os suportes de alguma coisa calculável, um ponto sem divisão nem extensão, sem passado e sem futuro, sem consciência nem inconsciente, sem corpo. Liga-os uma mensagem (M): enunciado sem enunciação, fala sem sujeito. Levado a sério, esse conceito remete os seres falantes à categoria de puros esṕritos, anjos, os quais, desprovidos de um corpo, fluem uns nos outros, nada havendo que barre a comunicação, a compreensão, o diálogo. Ressalve-se que, na vertente materialista, a ideologia, o esṕrito maligno dos poderosos, é responsabilizada pela viseira que, cegando, impede a visão correta do real ou a apreensão da mensagem verdadeira.

A despeito disso, porém, o par de locutores (E/R) que o modelo une ế a imagem e, nesse sentido, a máscara mais apropriada de uma impossibilidade real, reproduzindo aquilo que, de formas distintas, e tratado numa determinada vertente filosófica que, de algum modo, é dominante e, na psicanálise, como o nó da questão: a impossível conjunção dos seres falantes.

Uma junção que não se pode realizar, eis o que retoma e representa o modelo da comunicação e, por isso, afeta-o também a complexa problemática que se define sobre o fato de que os seres falantes são real e necessariamente distintos e, de nenhum ponto de vista, essa diferença pode ser preenchida: eles não cessam de se escrever como discernf́veis e nenhum real existe em cuja relação possam se tornar simétricos. Essa afirmação marca a diferença entre a tese que implícita ou explicitamente sustenta o modelo da comunicação, tal como é hoje aceito e difundido, e a tese psicanalítica. A primeira propõe que o homem é dotado de corpo e alma (ou matéria e esṕrito, ou qualquer outra duali- 


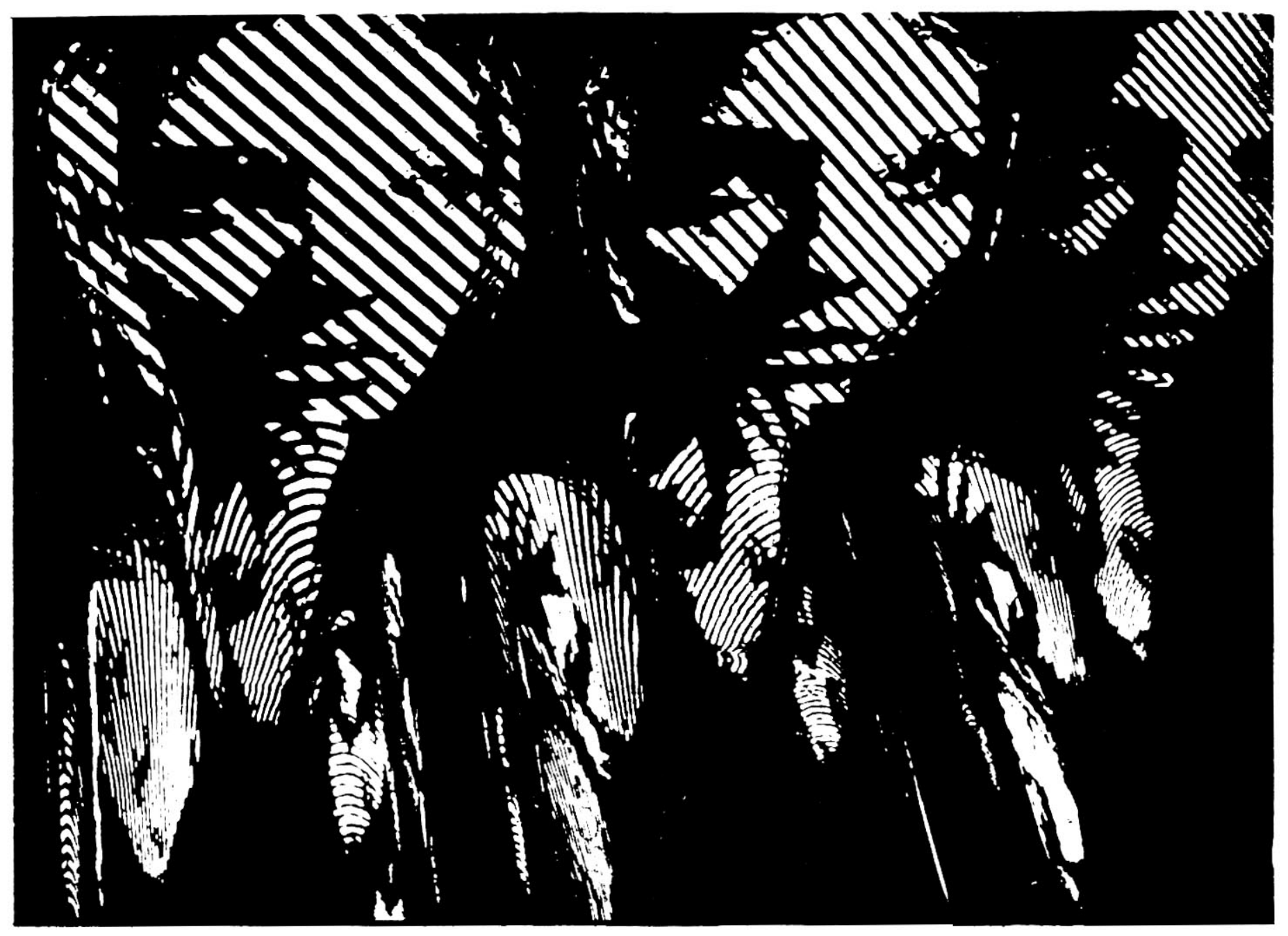

dade estabelecida no preceito clássico) e considera o corpo como o suporte de uma representação pela qual se apreende o movimento da alma; a segunda, considerando que, sexuado e falante, o corpo é o suporte de uma impossibilidade: a impossibilidade de que um corpo e outro corpo façam um, falam e, por falarem, corta-os o desejo.

Af́ se propõe que ser e falar são amarrados de tal forma que um corrompe irremediavelmente o outro, pois haverá sempre um ponto na ordem da língua que, movido pelo desejo, perverte toda a organização (amarração), lugar de um encontro que Mallarmé chama de acaso e Lacan de contingência.

As conseqüências de uma ou outra forma de pensar a questão também são divergentes: a primeira supõe uma consciência que, de tropeço em tropeço, um dia chega ao Absoluto; a segunda supõe um saber que age e que, sabido, se gasta a cada apreensão. Talvez possamos ainda dizer que a primeira propóe o progresso e a segunda a subversão. Em ambas, porem, quer se considere a linguagem como conceito, como na tese filosofica, ou a língua como lugar do significante, como na tese psicanalítica, o que está em jogo ê o estatuto desse real que, se o entendemos como referido à impossibilidade, é representável ou não.

$\mathrm{Na}$ tese psicanalítica, a questão passa pela questão da verdade, enquanto af as palavras faltam, e que, nesse faltar, porque não sendo toda a verdade, tocam o real. Talvez seja isso o que diga "o mito de Babel, uma vez que liga a possibilidade da língua a uma divisão indefinida e não adicionável"'(19).

$\mathrm{Na}$ tese filosófica, a questão da verdade passa pelo conhecimento, falso ou verdadeiro, substância e aparência, processo que se faz por intermédio de uma representação na linguagem. A comunicação, no entanto, na retomada do modelo e da impossibilidade, pressionada pela operacionalidade e pela inediatez, traduz a língua em termos de realidade, situando-a na rede da utilidade, a título de instrumento, ou na rede das práticas

19 Op. cit., Daniel Sibony, p. 67.

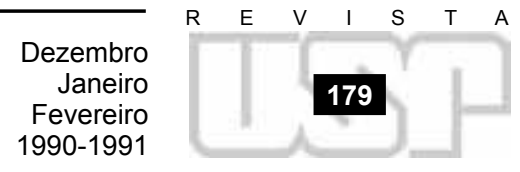


sociais, a serviço da ideologia.

A comunicação encontra, por isso, na teoria lingürstica de F. de Saussure, um verdadeiro arsenal: a língua proposta como um sistema de signos, governados por regras estabelecidas, permite uma espécie de territorialização, perfeitamente controlável (o controle funda as ilusões da comunicação), na qual os sujeitos falantes são supostos pelos traços que os igualam uns aos outros. São supostos, porque o signo que fundamenta a teoria lingüfstica, constituf́do como idêntico a si mesmo, é ajustado sobre um silêncio, onde se dá justamente a foroclusão do sujeito falante. Esse fato preocupava Saussure, tanto que pensando esse sujeito como uma manifestação particularizada, enviava-o para o campo da psicologia (lugar da alma) ou da antropologia (lugar do homem). Preocupava-o ainda porque, leitor dos versos arcaicos, já percebia, af, alguma coisa a mais, além ou aquém das mensagens organizadas na língua enquanto sistema de signos, isto $\hat{e}$, um código. Pois ouvia as mensagens que provinham de um Outro código, vindo de Outro lugar.

A esse respeito, Barthes faz a seguinte observação: "Um outro Saussure existia, sabe-se, aquele dos anagramas. Esse ouve, já, a modernidade no burburinho fônico e semântico dos versos arcaicos: então, não mais o contrato, não mais a clareza, não mais a analogia, não mais o valor: o ouro do significado e substitufdo pelo ouro do significante, metal não mais monetário, mas poético. Sabe-se quanto essa escuta atormentou Saussure, que parece ter, assim, passado sua vida entre a angústia do significado perdido e o retorno terrificante do significante puro"(20).

É da suspeita provocada por esse desconhecido que trabalha na rede da língua, que termina o sonho, o qual, conjurando a morte, o tempo e a anarquia, porque conjurando o corpo, permitia pensar através de um conceito redentor - o "valor", uma necessidade vital para a língua e, com ela, para toda a sociedade: um sistema de regras: regras econômicas, regras democráticas, regras estruturais, que aproximam esses sistemas entre si e tornam, a todos, semelhantes a um jogo (jogo de xadrez, metáfora central da lingüística saussuriana). "A língua se aproxima do sistema econômico a partir do momento em que esse abandona o padrão ouro, e do sistema polf́tico a partir do momento em que a sociedade passa da relação 'natural' (eterna), do príncipe e de seus sujeitos, ao contrato social dos cidadãos. $\mathrm{O}$ modelo da lingüística saussuriana é a democracia; não vamos fundamentar nosso argumento na situação biográfica de Saussure, notável genebrino, conterrâneo de Rousseau; marquemos somente, que uma incontestável homologia liga, no nf́vel epistemológico, o contrato social e o contrato lingüistico"(21).

Essa citação permite-nos entrever de onde o modelo da comunicação tira sua força operacional e política: o sistema de regras (o código), fundado na noção de valor, propicia uma série de elaborações, algumas mais ricas, outras empobrecidas, de uma questão que pode ser dita de várias formas:

- no campo pedagógico: como elaborar o código para educar o povo?

- no campo religioso: como elaborar o código que liga a Palavra de Deus à pobreza do pobre?

- no campo político: como elaborar o código que liga o partido às massas retrógradas? e que, finalmente, traduzem: como governar as palavras e, com elas, governar?

Deixemos, para o momento, essa questão em suspenso que, como um zumbido no ouvido, persegue, também, o quarto poder (a Imprensa), e finalizemos esta etapa do trabalho.

Nas considerações que fizemos, no sentido de delinear uma maneira para pensar a nossa primeira problemática - a problemática da práxis da comunicação - encaminhamo-nos para a interrogação sobre a linguagem que, quer seja pensada como representação do real, quer seja pensada como o sistema de significações que suporta a realidade, quer seja pensada como o lugar do significante, aponta para um ponto, onde se faz o no, isto $\epsilon$, a relação de impossibilidade. O conceito da comunicação opera sobre o modelo que, talhado nas dimensões do real, retomando por isso a relação de impossibilidade, resolve-a pela postura da língua-instituição, língua-realidade, negando a própria relação que o fundamenta, mascarando-a, de onde resultam uma série de conversões que transformam o efeito de impossibilidade em marcas contrárias: a topologia de não-conjunção se torna espaço da comunicação, a heterogeneidade dos seres falantes é contada

20 "Saussure, le signe, la démocracie", Roland Barthes, in Le discours social (3-4), p. 87.

21 Idem, p. 87. como homogeneidade dos parceiros da troca, os fragmentos da locução se fazem mensagem, das quais a língua é o código.

Mantenhamos esses pontos e passemos à discussão da segunda problemática: aquela que diz respeito ao conhecimento. 


\section{O conhecimento}

Vamos entrar nessa parte por uma porta já antiquada: a notícia, hoje substitufda por informação, melhor adequada ao cientificismo moderno.

Em Cícero, vamos encontrar uma definição de notícia, que utilizaremos porque nos permite fazer uma aproximação que julgamos interessante para o prosseguimento desse trabalho. Diz ele: "Notícia é a idéia ou conceito que fazemos de alguma coisa, o conhecimento" e também, "porque (essas coisas) eram conhecidas".

Se tomarmos como base de proximidade os indicadores de tempo: o presente, "fazemos", e o pretérito, "eram", não nos parece de todo desautorizado fazermos a aproximação entre essa notícia (notitia e propter notitiam) e a notícia jornalística propriamente dita. Pois o "fazimento" de uma idéia, de um conceito sobre alguma coisa (o conhecimento), porque "eram" conhecidos, remete-nos para o nó do trabalho jornalístico: o fato é feito porque já era. Se assim o for, dificilmente podemos conceber uma notícia inédita, uma informação inédita.

Tomemos como hipotese o que acabamos de dizer. Para desenvolvê-la, verifiquemos primeiro o que é esse conhecimento, ou seja, para onde olha e escuta o jornal para alimentar esse cotidiano ato de captar, produzir e divulgar as notfcias. Basta conferir as editorias para saber: é o universo todo, o mundo todo, a sociedade toda. (Há até um jornal que se chama $O$ Mundo, outro que se chama Globo e ainda outro que se chama $O$ Tempo; outros, mais modestos, restringem na denominação o lugar amplo de sua enunciação - do Brasil, de São Paulo, etc.). Importa-nos, nesse momento, lembrar que para cada pedaço desse Todo, o jornal propõe um Tudo dizer. Vejamos, agora, o que implica a suposição do Todo.

Duas condições, pelo menos, deverão ser satisfeitas para que um Todo seja Todo: primeiro, $\varepsilon$ preciso que haja um limite que, interrompendo o Todo, garanta-o como Todo, constrúfdo de uma maneira determinada, sem o que o Todo não seria Todo; segundo, é preciso que o Todo se substantifique numa rede de obrigações e proibições, de tal forma que o que $\varepsilon$ af impossf́vel só se inscreve a título de interdito, o que gera um paradoxo: o que é impossível deve, em acréscimo, dar lugar à proibição. Assim o Todo se mantém sobre um outro, do qual ele lembra a incessante possibilidade, o não-todo. $O$ Todo deve estar presente em cada uma de suas partes, mesmo e repetidamente, fazendose dessa forma (re)conhecido e reiterado, pois pode haver sempre o risco de que o não-todo, fixando-se em algum ponto, venha a se universalizar, isto é, a satisfazer às duas condições anteriores.

Tentemos, a seguir, pensar o tudo dizer. O jornalismo valida a onipotência do dito no estabelecimento de uma técnica redacional, cada vez mais elaborada, cada vez mais desesperada. Basicamente, essa técnica é estabelecida por um método que consiste em "retraçar os modos de construção possfveis de uma proposição universal", de forma que, ar, se possa mostrar como o todo vem aos pedaços, sendo que esses pedaços podem ser rejuntados por operadores que a cada momento lhes dá um sentido e tornam todo o Todo.

A pergunta: quem, que, como, onde? resume os operadores do "bricolage" que organizado por esse meio, como um Todo, obedecendo à regra do Todo, à sua lógica, adquire, assim, significação para qualquer um, sujeito universal, seja ele Humanidade, Povo, Liberdade, ou mesmo burguesia, proletariado (metades de um todo), conforme a representação metódica que se faça da sociedade. Podemos, ainda, rebater o "tudo dizer" sobre o conceito mesmo de língua: "de um lado representa uma totalidade abstrata e enunciável, votada, desde que é representada, ao estatuto de fantasma; $\hat{\varepsilon}$, af, a línguarealidade que $\varepsilon$ interpretada como instituição, como competência, como conjunto de práticas, etc. Mas de outro lado, e sem que seja possível separar os fios, a língua suporta a barra do impossfvel, ... suporta o real que, bordas ilimitadas, desfaz toda universalidade ... esse não-todo que imprime sua marca e introduz uma inquietante estranheza nas cadeias da regularidade"(22).

Supor esse "tudo dizer" e "ocultar o real lingüístico, isto $\varepsilon$, a possibilidade de múltiplos sentidos na significância. Ocultar o real lingürstico que na língua produz o equívoco, a possibilidade de uma segmentação sempre outra da cadeia significante e de um deslocamento do sentido. Real que freia o poder. Sujeito à insubmissão da língua, este não pode recuperar de uma vez por todas as palavras, fixar definitivamente o sentido existente"(23).

Tudo dizer, era o desejo de Artêmio Cruz frente ao corpo morto de Regina: "Nunca

22 L'amour de la langue, Jean-Claude Milner. Paris, Seuil, 1978, p. 118.

23 Op. cit., Bety Milan, p. 83.

\section{Dezembro \\ Janeiro \\ Fevereiro} 1990-1991 
24 Idem, p. 40.

25 Op. cit., Jear-Claude Milner, p. 89.

26 Te Séminaire sur la lettre volée", Jacques Lacan, In Ecrits. Parls, Seuil, 1966, pp. 11-54.

27 Des miroirs equivoques. Aux origines de la communication moderne, Louls Quéré. Parls, Aubler Montalgne, 1982, p. 140.

28 Arts de faire, Michel de Certeau. Paris, Union Générale des Editions, 10 18, 1980. pp. 240-1.

29 Idem, pp. 240-1

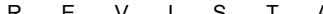

houve tempo para a úlima palavra". Houvesse um tempo, falaria. E chorava. Teria havido um tempo. Não há mais tempo. Encontro perdido, real encontrado no tempo da Morte.

Encarcerado no preceito, o conhecimento que o jornal aspira é uma variação ilimitada de um mesmo movimento que transforma as diferenças em oposições, apaga-nas, embrulha-nas ou as atola definitivamente, aspirando-as no redemoinho de um mesmo ponto de atração. É que as regras, as normas, os manuais fazem tudo convergir para um sítio único: o significante um, figurando-se nos seus efeitos.

Mesmo se articulações outras às vezes emergem, como mostram M. L. Montes e M. Meyer no estudo "A festa na política", ar se rebatem, ricocheteiam e caem no silêncio, mas por um momento, um momento único, mostram a fratura, a vertiginosa fenda. Dar, aos borbotões ou no tartamudeio, saem as palavras que, ordenadas no trabalho universitário, dão-se a ver, como o saber do $S_{1}$. Fica, porêm, a memória. Que o jornal não registrou.

Para concluir esse pedaço, digamos ainda que o anteparo desse movimento, barrando neste o deslizamento dos significantes, dando "a carteira de identidade das palavras, tenta imprimir-lhes um significado único. Viola o processo de diferenciação intrínseco à língua, instituindo uma conformidade entre a designação e o objeto que ela designaria: a cada proposição uma denotação. Decreta-se af a unidade na língua..."(24). É essa exigência de unicidade, de completude, que toma uma coloração imaginária e se transpõe em termos de totalidade: "totalidade qualitativa", quer dizer, uma redação bem feita; "totalidade quantitativa", que não admite uma notícia que não seja completa, pois "a imagem de uma totalidade não pode ser ela própria, senão total". Dessa forma, o real que provoca o movimento, que o constitui, af se embrulha e rola, convertendo-se em realidade social e nos mitos que a suplementam.

É nesta realidade, que é parte do campo imaginário, que se instalam a comunicação e o conhecimento. É nesse campo que está o tecido do representável: o possível, a semelhança e a dessemelhança. É no imaginário, também, que se instauram o espaço e o tempo, como modos especificáveis de relação, cujo cruzamento determina todo o evento possível. O imaginário é, por isso, o lugar que liga, o lugar em que o discurso se assenta e, ar, dá o laço social. É por isso que nesse lugar se instala, ordenada, articulada no princípio do $S_{1}$, a comunicação. Mas é ấ mesmo onde o imaginário "liga" que, aquilo que Lacan chama o simbolico, “distingue”: não há todo, não há relação.

$\hat{E}$, ainda, nesse imaginário, que o real, enquanto o indistinto, o disperso, que Freud opunha como Tanatos a Eros da união, "num espaço, fora do espaço, num instante fora do instante, produz uma 'fenda' nua, que se confirma nos efeitos de dispersão que ocasiona"'(25).

As três instâncias (real, simbólico e imaginário) estão presentes em toda a problemática da comunicação, onde a linguagem não ê tão somente um instrumento utilizável mas, ao contrário, um lugar de determinações.

A linguagem é, nesse encaminhamento, o cristal de Aleph de que fala Borges, indicando o lugar não-idêntico no qual todo o ser falante se coloca. Ar a comunicação é mobilizada por uma combinatória na qual o Poder $\left(S_{1}\right)$, o Saber $\left(S_{2}\right)$, o Sujeito $(\$)$ e os objetos do desejo (a) formam uma equação distingứvel a cada momento da vida. $\mathrm{O}$ ponto de partida se dá, efetivamente, em relação ao Poder e teríamos, assim, como fundamento da comunicação, a seguinte equação:

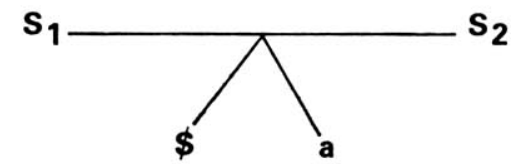

A relação $S_{1} \longrightarrow S_{2}$ indicando a função metafórica do $S_{1}$ que, no entanto, desdobra-se segundo uma lógica metonímica, isto $e$, o puro envio de uma à outra de suas máscaras. Nesses envios podemos ver a bateria de significantes designada por $\mathrm{S}_{2}$, onde todos se equivalem e valem apenas por sua diferença na composição dos significantes do saber.

Nesse discurso, o trabalho do $S_{1}$ tem como efeito a negação da falha (A): a falha no sujeito, a falha no lugar do Outro, de maneira que o seu desdobramento se dá conforme a dialética da negação da falta. O traço que não une, mas disjunta a relação $S_{1} S_{2}$, tem uma função: é a barra/barreira que, ilusão de onipotência e onis- 
ciência, bloqueia a emergência do sujeito $(\boldsymbol{X})$ na relação determinada e determinante com o desejo (a). No entanto, isso fala nos interditos, nas entrelinhas, no desconhecido, na purloined letter(26).

Há, porém, nessa articulação, nuances necessárias, créditos que devem ser concedidos, no caso do discurso jornalístico. Este se organiza em relação ao saber suposto na informação. Saber referido, com insistência, à entidade posta como "real" e pensada como verdadeira. Por esta razão esse discurso é sustentado por uma competência profissional, isto $\epsilon$, "por um saber-fazer reconhecido e formalizado, consistindo no controle e na verificação de enunciados, na elaboração e na validação de hipoteses, na fabricação de cenários com a ajuda de uma tecnologia intelectual, objeto de um aprendizado"(27).

Tais procedimentos, que podem ser mais ou menos avançados dependendo do estado da tecnologia com a qual podem se cercar, movem-se entre duas fronteiras: o real dando o ponto de partida e o real desejado como ponto de chegada. Por isto, postulado como causa ou como produto, o real é o fantasma da escrita jornalística que segue na sua impossfvel trilha. Não ê em vão que o discurso se desdobra, incessante e incansavelmente, em provas, testemunhos, dados estatísticos, no cerco daquilo que lá estaria e que, impossível, escapa.

Há ainda um outro discurso que, por mérito, tradição e reconhecidos efeitos, visa essa coisa que se pode chamar de real: é o discurso do saber produzido pela ciência e que, de uma forma ou de outra, cria o mundo contemporâneo. No processo dessa criação, vai penetrando pelos interstícios da sociedade, saber disseminado, alimentando o imaginário e agindo no sentido de transformações, mais ou menos lentas, em todos os domínios. O domínio jornalístico, talvez mais do que qualquer outro, absorve as derivações daquele saber. Não nos parece precipitado, assim, afirmar que o discurso jornalístico é tributário do saber produzido pelo discurso cientffico, fazendo-o porém numa visão de utilidade e de operacionalidade. A tributação prestada ao discurso cientifico altera a combinatória acima proposta. A alteração não significa uma transformação subversiva, pois o Poder $\left(S_{1}\right)$, agora na sombra, sustenta as produções do fazer jornalístico e do discurso, assim produzido - a escrita desenha os traços de sua servidão.

\section{A Servidão: O LUGAR-COMUM, O PODER POlf́tico}

A fantasia que anima a escrita e arma as artimanhas da sedução nos impele a dizer que o jornalismo surge no conjunto desse imenso esforço que as sociedades realizaram para se constitufrem sem a Voz de Deus, isto $E$, quando Deus deixou de falar, surgiu no mundo a comunicação social ${ }^{(28)}$.

Diz M. de Certeau: "Quando desaparece o Primeiro Interlocutor aparece o problema da linguagem como um fazer e não mais como um ouvir"(29). Este problema, "a linguagem como um fazer", marca no jornalismo uma bifurcação: de um lado, a linguagem $\varepsilon$ posta como o instrumento de um fazer, de outro, e a propria linguagem esse fazer. A primeira via dessa bifurcação re-


força a crença e o imaginário, obscurecendo

a segunda, esta mais próxima da verdade e, ignorada, não se constitui em alvo de questões; por isso, aqui tem procedência aquilo que, em outros lugares, é libelado como alienação.

Nesta contingência, a ação cotidiana que se desenvolve no lugar circunscrito da linguagem, onde se ordena a prática jornalística e a lógica que a governa, é orientada pelo ideal de cientificidade, expresso no fazer correto, e desenha, em filigrana, a escrita e sua servidão. 


\section{Os fatos falam por si}

“Os fatos falam por si" é uma afirmação da verdade jornalística, cabendo à prática a acolhida dessa fala, modelando-a num relato. Este procedimento se faz sob uma condição: que nesse relato sejam apagadas as marcas da passagem do "eu" que escreve. Essa condição é necessária para que o fato, na sua integridade (a verdade), limpo e sem nenhum rứdo, não se contamine pela escória, a abjeção, o excesso: "eu".

Flaubert ${ }^{(30)}$, a quem devemos essas postulações, dizia que a presença do eu no escrito causava-lhe dor e vergonha: "Pourqu'il croisse, il faut que je diminue"(31). Fazendo repercutir sua fala no jornalismo, poderfamos dizer o seguinte: para que o fato seja, é preciso que o peso verbal da primeira pessoa desapareça e, com ela, a fantasia, o sentimento, a mera opinião. $\mathrm{O}$ apagamento do eu na ordem das conseqüências é seguido pelo desaparecimento da imagem, porque não havendo imagem que não a imagem especular, constituindo assim índice da presença indesejável, deve ser sombra dissipada, na escrita.

O "eu" ausente, o que significa a ausência de "eu escrevo", é substituído pela impessoalidade: "escreve-se", onde esse "se" reflexivo é a negação do ato de escrever. Instaura-se, nesse movimento de negação e de substituição, o que poderfamos chamar de: a servidão da escrita. E, com ela, uma voz antecedente, um olhar vigilante que profere as frases, que ordena o relato, que diz do correto e do incorreto, que precipita a certeza. Essas considerações nos indicam que a abolição do "eu" e o não cessar da escrita necessária implicam, reciprocamente, na inclusão de outra coisa que não cessa de se escrever.

\section{O lugar-comum}

Interessa destacar, nessa servidão do escrito, que não é tanto a presença desse outro que vigia e que possa vir a ser identificado ou imaginado, ou mesmo que detivesse a verdade daquilo que vai ser registrado, que importa. O notável é que, na servidão, o escrito obedece ao esforço constante para não cometer erros, como se aquilo que vai ser registrado, já o tivesse sido em algum lugar, como se já existisse na exatidão que deve registrá-lo. A apresentação de provas para o fato relatado, o escrito do que já foi dito, seguem nesse processo, pois a invocação de testemunhas, dos que viram e ouviram e que, proferindo enunciados que se garantem na propria enunciação, tecem a interminável rede do foi-não-foi, adquirem sentido na servidão, sendo o que se procura $e$ o lugar alhures, onde a afirmação exata estivesse já dita.

A postura da impessoalidade, permitindo-nos deduzir a instauração da alteridade, conduz a argumentação para o nosso ponto de ancoragem: esta certeza procurada, esse já-escrito em algum lugar (pois é disso que se trata) leva-nos para o lugar do acordo firmado, na língua, como se, dobrando-se sobre si mesma ela fizesse ecoar a dúvida e precipitar a certeza, a pergunta e a resposta.

É, sobretudo, nessa dobradura pela qual a voz ecoa, que as frases proferidas, o relato ordenado são entendidos. Se tomamos um exemplo no próprio jornal, encontramos af o fait divers que, apresentados sem nenhuma referência, a não ser a que trazem inscrita sobre si próprios, dando-se a ler como se tivessem se escrito, são, não obstante, entendidos.

A explicação usual, remetendo para o conhecimento acumulado, a informação geral ou a cultura, não esgota a questão. Reunamos os elementos que fomos destacando: a escrita sem emissor, o que a instaura como uma alteridade isenta de qualquer indicação pessoal, preservando apenas a impessoalidade vaga e imprecisa de dispersos signos de reconhecimento. Esses signos nos apontam a presença de um frágil tecido de significações que, portanto, pode constituir o suporte de um laço social. Esse laço, por sua imprecisão e fragilidade, vem a ser o suporte mais elementar e, ao mesmo tempo, mais universal de uma primitiva socialidade. Nos nossos termos, esses signos de reconhecimento, esse impreciso tecido de significação, são massas flutuantes de significantes que, formando cadeias mais ou menos estáveis, arcaicas, compõem um substrato na língua, um saber acéfalo, talvez resistente, comum justamente àquilo com que se ocupava Flaubert: o lugar-comum.

O Dictionnaire des idés reçues mostra-nos o registro daquilo que ele denomina a

30 Ct. O trabalho de Dominique-Gilbert Laporte. Le lieu commun. Ornicar? (20-21). Paris, Seuil, 1980, pp. 281. 306.

31 Idem, ibidem. besteira do mundo: esse anônimo rumor da língua, que efetua a sua literalidade, quando daf se retiram as figuras, as pessoas, os postulados de identidade, tudo aquilo que evidencia o lugar da emissão da fala, isto é, quando não se encontra na sintaxe nenhuma solução interna para responder: quem fala? 
Como poderfamos dizer quem fala nos verbetes do dicionário das idéias herdadas? Um burguês? Um liberal? Um republicano? Um monarquista? Quem fala nos dicionários?

Conclú́mos, aqui, propondo que essa repetição anônima causando a exclusão de quem fala de sua própria fala, atravessa-o dividindo-o e retirando o tributo devido. Gostarfamos de destacar ainda que, dobradura infinita da língua, Outro irredutfvel a uma identidade; ninguém fala nesse lugar. Mas esse impessoal passivo do lugar-comum, constituído pelo encadeamento de sintagmas, sustenta sua legitimidade unicamente no apelo incessante que, de um a outro, sela o pacto dos seres falantes, agrupados por essa espécie de contas de rosário da língua.

De todo modo, o lugar-comum que suporta o laço social elementar, quase universal (de massa, se assim o preferirem), aproxima-se do correto fazer proposto na prática jornalística, pois é af que se justificam os efeitos de legibilidade e de inteligibilidade, que não têm outro apoio a não ser esse: lugar-comum, onde as frases corretas e, portanto, inteligf́veis, estão jå feitas e sabidas.

Parece-me possf́vel, também, concluir que a cientificidade desejada encontra nesse lugar seu desaguadouro e, mais ainda, é af que o jornalista, decapitado, submetido à lógica que o transcende, deposita sua oferenda sacrificial.

\section{O Poder Político}

Esse Outro, assim localizado, cena, drama e personagem, "tapete desenrolando-se infinitamente sobre o vazio", não é porém o único nessa escritura. Há uma outra dimensão da linguagem que, serva da significação, distinta do nada que mencionamos, sustenta-se no insustentável: os fatos falam por si: o que querem dizer? para que servem?

Enquanto o Outro, na impessoalidade, apagando as marcas do "eu", instala a alteridade, esse do qual agora tratamos, trabalha no efeito de identidade, resultado da suposta coincidência ou adequação do lugar da emissão e a mensagem, apreendidos como Um significado. Nos brancos deixados pelo espelho cego da falta de imagem instala-se a representação; do lugar do nada, espera-se agora o interesse: os fatos servem para e querem dizer. Estamos falando do Poder Político e, ao dele falar, na complexidade com que existe, hoje e aqui, nesse lugar, é difícil, tão simplesmente, localizá-lo no lugar do Estado, como centro irradiador de sua potência e, mesmo que o chamemos pelo nome $S_{1}$, expressando-se na sua função metafórica, metonímica é a sua lógica, mostrando-se na simulação.

\section{A representação}

Procuraremos aqui descrever os processos de representação que encenam os atos através dos quais se realiza a visibilidade do Poder: as máscaras, as simulações, as figurações de autoridade, a enunciação de um saber sobre o social, o estabelecimento de normas e condutas, as discriminações pois, em sendo Poder, ๔ Todo Poder, podendo e devendo fixar nas margens as proibições, de resto, sempre arbitrárias.

A representação é fundamental porque um Poder só sustentará a onipotência polftica se dela partilhar igualmente, uma representação perfeita, uma vez que dar dependem a produção de sua coerência, sua capacidade de determinar a história e o funcionamento da organização social.

Esse postulado exige uma reciprocidade e, como tal, identificação fictícia entre representação e Poder, que é, por isso, o senhor dos significados. A representação perfeita do Poder requer, essencialmente, um narrador que se situa na esfera do Poder, mas a uma distância que permita a contemplação dos atos e gestos do Poder-autor da história e do Poder-dominação da organização social, supondo-lhe o atributo da previsibilidade e a capacidade de transformar o impossível em possível. Essa dupla implicação desenvolve-se num relato capaz de organizar uma representação narrativa que, ao mesmo tempo, simule a capacidade de auto-engendramento da posição de poder e sua capacidade de engendramento da história e da sociedade.

\section{O relato}

O relato, porém, não pode ser um relato autobiográfico, ou seja, não se fará a partir do "eu", pois o Poder não conta a história, ele a faz. Impõe-se, dessa necessidade, uma estrutura narrativa tal que o sujeito da enunciação se apagando produza como efeito o Poder contando-se a si mesmo, na impessoalidade, portanto, nas histórias que o encenam. Esse efeito é obtido pela constituição do narrador dos feitos do Poder, em seu du-

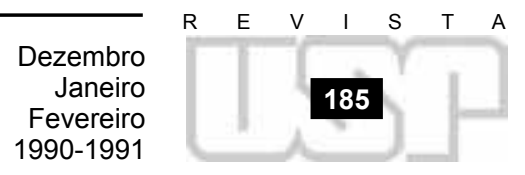


32 Op. cit., Louis Quéré, p. 167.

33 Écriture de I'histoire. Michel de Certeau. Paris, Gallimard, 1975 , pp. 14 $\theta$ segs.

34 "Écriture et Histoire", idem, in Politique aujourd'hui, nov-dez/1975.

35 "Fonction et champ de la parole", Jacques Lacan, in Écrits. Paris, Seuil, 1966, p. 244. plo fictício, o que, por sua vez, resulta na fictícia correspondência entre o olhar do narrador com o olhar do Poder. No espaço perspectivo, assim formado, monta-se a cena narrada e, por isso, só é visto aquilo que está no espaço perspectivo do Poder.

A conseqüência dessa armação, os chamados "agentes sociais", sర́ o são se se movem nesse campo estratégico do Poder, dele recebendo vida e movimento. É por isso que a parte do social que obedece a uma logica diferente daquela estabelecida pelo Poder, ordenadas por estatutos simbólicos particulares e mesmo práticas rotineiras, não emergem, pois, não recebendo o estatuto de informação, que só o Poder concede, não acedem à visibilidade a não ser como particularidade ou estranheza, opacidades subterrâneas.

A construção da narrativa, que deverá ter como efeito a representação perfeita, obedece a regras de um cálculo estratégico, sem o qual esse efeito não se produzirá. Primeiramente, há que se dotar o Poder de um querer e de um poder, dessas duas coordenadas se estabelece o seu campo de forças. O relato deverá, ainda, reduzir a contingência dos acontecimentos, narrando-os sob a forma de uma causalidade temporal e relacionando-os ao desenvolvimento do querer e do poder do Poder, ou seja, fazendo valer sua capacidade de previsibilidade e a propriedade de transformação do impossível em possivel.

Essas atribuições permitem a tradução do passado próximo em causas, transmutandoas, assim, em intenções e projetos, incidindo sobre os acontecimentos que, por esse meio, tornam-se um futuro desejado e, sobretudo, dominado.

Diz L. Quêre: “'Desdobrando assim o tecido da história, o narrador-informador transforma o relato do Poder em relato da origem da história e da organização social. Cria a ilusão da apreensão de uma e de outra, no momento mesmo de sua produção pelo Poder. E, ao mesmo tempo, ele instaura a temporalidade própria do Poder Político (de uma só vez linearização do tempo e visão de domínio ou de capitalização) em temporalidade de referência, permitindo a superação das contingências. Em outros termos, o tempo do Poder se torna o único fator de unificação temporal das ações e dos acontecimentos históricos"'(32).

Detenhamo-nos sobre a figura do jornalista-narrador, constituŕda na posição que o sustenta, fascinado, vis-a-vis do Poder. Para esclarecê-la, é ainda M. de Certeau que nos fornece os elementos. Ao analisar o historiador, cujo destino parece-me semelhante ao do jornalista, diz Certeau que "colocando-se no lugar do Príncipe para torná-lo visível, o narrador se faz de Príncipe que não é, pensando o Poder que não tem"(33).

Dessa posição ambígua, decorre a ambigüidade do relato: quem está ar, no lugar de quem? Pergunta sem resposta. "A violência do conflito corresponde à dissimulação do vencedor, mas uma dissimulação estrutural que torna impossf́vel a homogeneidade do eu com aquilo que nele aparece. Há uma de-fecção do lugar. Seu outro é ar, sempre, um que tem 'direito'."

Como escrevê-lo senão num discurso que recusa o postulado historiográfico de "sujeitos" identificáveis a lugares, e que faça da ficção o próprio motor de sua construção? Se o sujeito é qüiproquó, seu relato não pode ser senão uma narratização do qüiproquó: uma comédia da identidade ${ }^{(34)}$.

Narrador e Poder, de tal forma estão enredados na trama desse discurso que o ser do segundo suporta-se sobre o nāo-ser do primeiro, numa relação fantasmática, circular, porém assimétrica e não-recíproca. Herơi moderno habitando o imaginário social, talvez caiba ao jornalista a definição que o autor do seminário sobre a "Carta roubada" dá desse herói: "qu'illustrent des exploits dérisoires par une situation d" égarement"(35).



